\title{
Article \\ Impacts of Coastal Breezes on the Environment and Human Life: The Case of Mallorca (Western Mediterranean)
}

\author{
Gabriel Alomar-Garau*(D) and Miquel Grimalt-Gelabert (D) \\ Climatology, Hydrology, Natural Hazards and Territory Research Group, University of the Balearic Islands, \\ 07122 Palma, Spain; miquel.grimalt@uib.es \\ * Correspondence: gabriel.alomar@uib.es
}

\begin{abstract}
The sea breeze is an atmospheric phenomenon that can appear in many coastal areas of the world. On the island of Mallorca, in the center of the Western Mediterranean, the coastal breezes present prototypical characteristics. They are so consistent that their effectiveness allows for easy scientific verification. The sea breeze system is defined in Mallorca by its multi-directional spatial behavior and its unifying nature. As a result of the physical insularity of the land, coastal breezes have multiple orientations and act in opposite directions. This means that they can operate simultaneously on different coasts, and penetrate inland areas, where they typically converge, eliminating slope winds and forming convective chimneys, creating storms. In this article, we characterize and label the coastal breezes of Mallorca, and we verify their influence in the places where this phenomenon appears. A broader understanding of them reveals their remarkable influence on all spheres of life and human settlement: climatic, ecological, biological and geomorphological, but also cultural, territorial, economic and social.
\end{abstract}

Keywords: coastal breezes; sea-breezes geography; sea-breezes impacts; coastal geography; wind landscapes; Mallorca

Citation: Alomar-Garau, G.; Grimalt-Gelabert, M. Impacts of Coastal Breezes on the Environment and Human Life: The Case of Mallorca (Western Mediterranean). Coasts 2022, 2, 17-35. https: / / doi.org/10.3390/coasts2010002 Academic Editor: Giuseppe Roberto Tomasicchio

Received: 10 October 2021 Accepted: 24 January 2022 Published: 1 February 2022

Publisher's Note: MDPI stays neutral with regard to jurisdictional claims in published maps and institutional affiliations.

Copyright: (c) 2022 by the authors. Licensee MDPI, Basel, Switzerland. This article is an open access article distributed under the terms and conditions of the Creative Commons Attribution (CC BY) license (https:// creativecommons.org/licenses/by/ $4.0 /)$.

\section{Introduction}

In coastal areas, one of the most obvious atmospheric demonstrations of the relationship between the maritime and terrestrial domains is the sea breeze, a phenomenon defined by the World Meteorological Organization (WMO, 1992) [1] as "wind in coastal regions, blowing by day from a large water surface towards the land as a result of diurnal heating of the land surface". Indeed, when the sun heats a portion of the land's surface, the heated air in contact with it rises by convection, creating a horizontal pressure gradient that causes the cooler and denser air from the sea to blow inland in the direction of the lighter, rising air over land to fill the air void generated there [2].

Although the dynamics and structure of the sea breeze are known [3], its waft is associated with a complex set of phenomena. Its effects on the climate and local meteorology of many regions of the Earth have been ratified by the scientific literature, in which we find works on the impact of the sea breeze on summer air temperature [4-7], air quality in urban coastal environments [8], or on convective activity $[9,10]$. In this article we describe a summarized set of effects and benefits of breezes, with the aim of completing and expanding the field of their study. Breezes not only control the local weather and climate of coastal and inland areas, but also affect our lives in many different, often unusual ways, for example in historical events, such as the famous naval battle of Salamis (480 B.C.), in which the strategic prediction of the breeze helped the Greeks defeat the Persians [11,12]. Of course, breezes have also historically conditioned and continue to condition the territorial location of certain agricultural, energy and service infrastructures, as well as certain recreational activities related to coastal fishing, sun and beach tourism and sea sports. Information on sea breezes' characteristics is also of great interest to coastal cities [13]. They affect daily air 
temperature, relative humidity and precipitation, not to mention the wind regime [14,15]. These effects and uses are geographic, in the sense that they occur in the living space of men.

Considering that the impacts of sea breezes cover a wide spectrum of possibilities, we describe them for Mallorca because on this island these impacts are presented in an exemplary way. The breezes star in much of the island's atmosphere for at least half the year, to the point that they did not go unnoticed by travelers, storytellers and researchers of the 19th century. A first nineteenth-century reference is found in writings by the Archduke Ludwig Salvator von Österreich-Toskana, who in his monumental work Die Balearen in Wort und Bild ('The Balearic in word and image', 1871) [16] (pp. 12-25) described how "around ten o'clock in the morning, every day, or almost every day, a sea breeze rises, named 'embat', very pleasant, which softens the heat; it lasts all day and dies out at sunset. These winds are not constant and on many days there is dead calm. The 'embat' is a fresh breeze in the proximities of the coast, but inland it is warmer and weaker".

A second interesting reference, of a scientific and descriptive nature, can be found in a book of 1854 by the military doctor Fernando Weyler [17] (p. 55), entitled "Topografía físico-médica de las Islas Baleares y en particular de la de Mallorca", which explained the insular characteristics of these local winds, which "blow in different directions and are damped when strong winds are present". In more recent times, the Mallorcan local winds were specifically referred to in a canonical book by Simpson [2], Sea Breeze and Local Wind, in which the author highlighted the formation of convergence areas due to the collision of sea breezes blowing from opposite coasts. The scientific interest in this phenomenon in Mallorca has not diminished, and international studies are still underway to study the island's sea breeze.

\section{Formal Characteristics of Sea Breezes in Mallorca}

Due to its physical dimensions (3619 $\mathrm{km}^{2}$, approximately $\left.100 \mathrm{~km} \times 80 \mathrm{~km}\right)$ and its latitudinal position $\left(39^{\circ} \mathrm{N}\right)$, close to the subtropical world and favoring the predominance of anticyclonic weather, Mallorca, located in the center of the Western Mediterranean, is an ideal geographical setting for the development of a typical sea breeze system during the daytime cycle, and a land breeze system at night, especially under conditions of a low or no atmospheric pressure gradient on the synoptic scale.

From a physiographic point of view (Figure 1), the island has two mountain ranges on the northwestern and southeastern sides, separated by subsident basins that constitute the bays of Palma and Alcúdia. There are, therefore, three main morphological units, corresponding to three different landscape regions. The first is the Tramuntana mountain range (Serra de Tramuntana), located parallel to the western coast, about $90 \mathrm{~km}$ long and $15 \mathrm{~km}$ wide on average, with an average height of about $800 \mathrm{~m}$, reaching an altitude of $1445 \mathrm{~m}$ at puig Major. The second is the Llevant mountain range, parallel to the eastern coast, which is an uneven alignment of hills with altitudes not exceeding $600 \mathrm{~m}$, totaling approximately $46 \mathrm{~km}$ in length and $10 \mathrm{~km}$ in width. Thirdly, an extensive central area-the "Pla", a name used more for its opposition to the surrounding reliefs than to describe a physical reality - is composed of open valleys and small, modest reliefs, and joins the two large bays located to the north (Alcúdia Bay and Pollença Bay) and to the southwest of the island (Palma Bay).

The main precursor of the study of the breeze regime in Mallorca is the work of the meteorologists J.M. Jansá and E. Jaume, entitled "El Régimen de Brisas en la Isla de Mallorca" (The Sea-Breeze Regime in the Isle of Mallorca) published in 1946 [18] in the Revista de Geofísica (Geophysics Journal) of the Consejo Superior de Investigaciones Científicas, Spain. In this work, the characterization and modeling of the dynamics of the breeze system is qualitative and is based on the conclusions derived from a campaign of surveys to farmers and fishermen of the island [19], who gave key oral information to understand the general scheme of the spatial behavior of the diurnal breeze. According to this scheme, the island constitutes a space within which maritime flows radially penetrate 
and converge from different coastal origins, mainly the bay of Palma to the southwest, the bays of Alcúdia and Pollença to the northeast, and the Llevant coast to the east. The western coastal side is very weakly affected by the breeze due to the buffer effect, as a barrier, imposed by the orographic screen of the Tramuntana mountain range. The height and elongation of this mountain range inhibits the attraction effect of the thermal lows formed in the interior zones of the island. This scheme is represented in the map in Figure 2, a reelaboration based on a Digital Elevation Model of the map of the maritime currents of the breeze, elaborated by Jansá and Jaume [18]. The orography and thermal contrasts alter these winds and cause local maxima and minima.

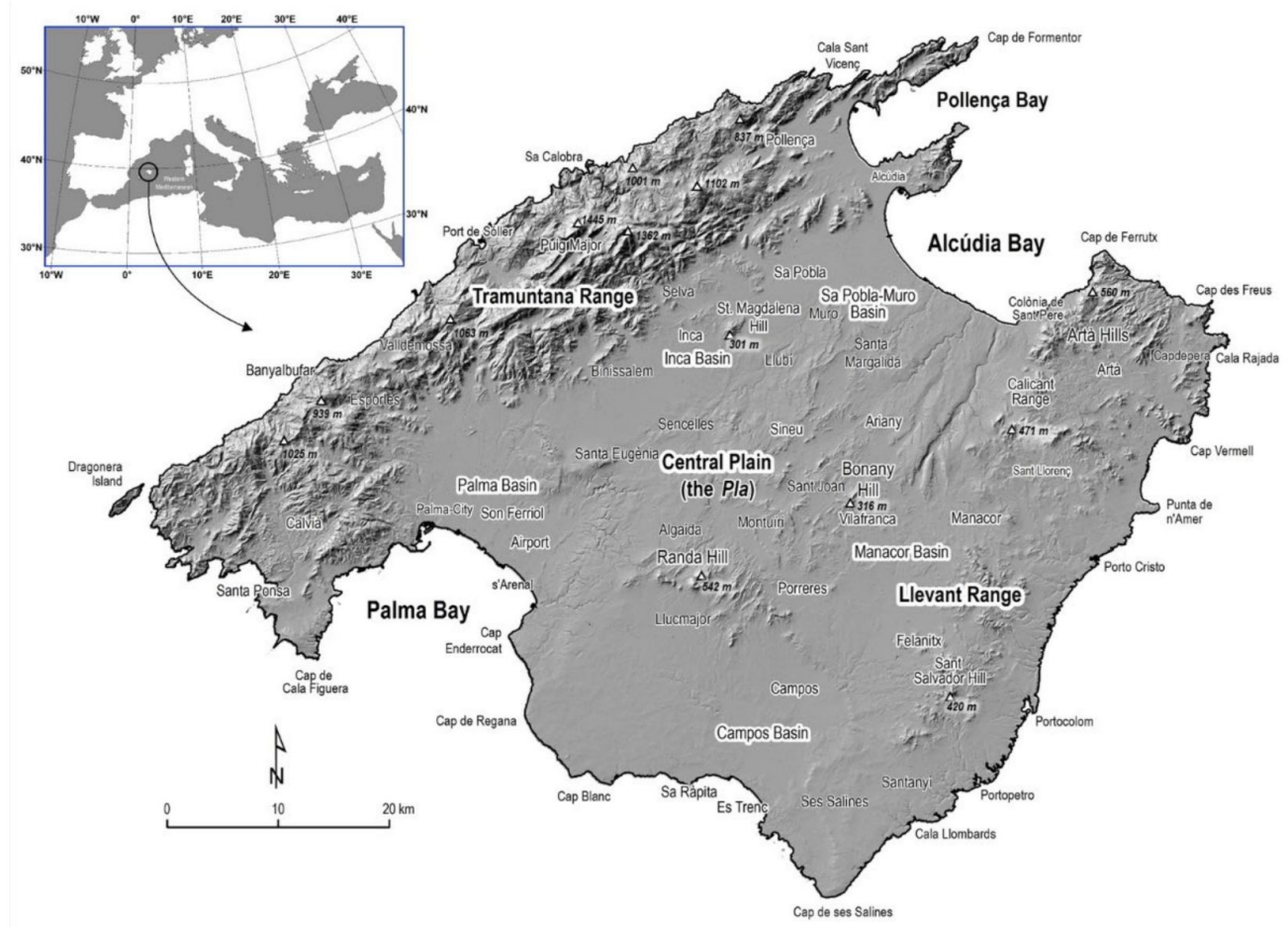

Figure 1. Geographical framework of the isle of Mallorca.

Mountainous areas and their slopes determine in many cases the distribution of surface heating, and thus the locations to which the breeze is attracted. The breeze may become embedded with thermal flows originating in the interior, as is typically the case with the slope winds, which are adiabatically warmed during the day, thus attracting the breezes. It may also be the case that thermally induced local scale circulations start earlier in mountain areas than in coastal areas, due to a more effective heating of the slopes, so that during the day the convective circulations developed in the mountainous areas merge with the sea breezes. The breeze unfolds, fanning out when it finds natural ways of penetrating inland, such as those formed by deep coves and the mouths of valleys.

The inland horizontal reach of the breeze is a few tens of kilometers, taking into account that, in Mallorca, the maximum distance to the coast corresponds to a point located $24.1 \mathrm{~km}$ from the coastline. This is enough for breeze fronts to reach certain inland areas, constituting convergence areas with interesting local meteorological repercussions [20,21]. For example, when the absorption of the moist breezes by land is high and there is instability, a high 'vertical draft' is initiated that generates storms $[20,22,23]$. These storms are reinforced by moist air added by the breezes. If a depression arrives in the region, the wind associated with the disturbance kills the individuality of the breezes, which are thus masked or annulled. 


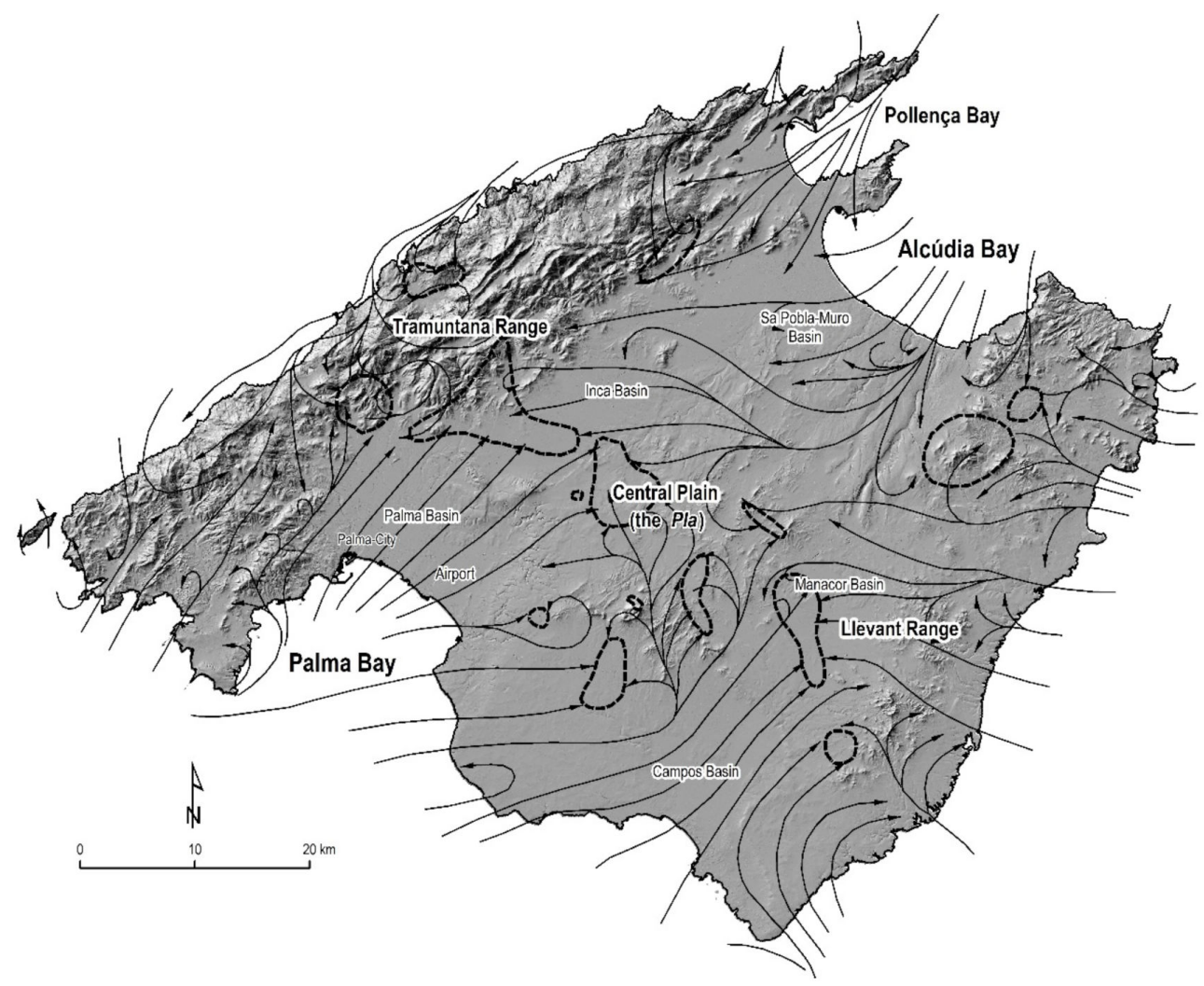

Figure 2. Sea-breeze current lines around the isle of Majorca (continuous line) and convergence areas (closed dashed lines). Own redrafting based on data from Jansá and Jaume [18], drawn using a digital elevation model (DEM).

From a climatic point of view, breezes can occur throughout the year, although they do so mainly from spring and throughout the summer-that is, from April to September, the warm season in this Mediterranean latitude-and very irregularly in the cold season. This is especially valid in coastal locations, because one of the most important peculiarities of these areas is precisely the existence of very well-defined breeze regimes. The numerical simulation carried out by Ramis and Romero [21] shows that the daytime breeze starts around 9 a.m. local time, and becomes fully mature around 3 p.m. The system dissipates completely by around 9 p.m. local time or earlier.

During the early afternoon, maritime air currents penetrate inland in response to the overheating of inland areas and the corresponding air suction. The main currents penetrate from the SW in the bay of Palma, from the NE in the bays of Alcúdia and Pollença, and normally from the SE (or similar) on the eastern side of the island. The wide plains of Palma, Sa Pobla-Muro and Campos make it easier for the breeze to flow, while on the eastern side-Llevant - the breezes are normally weaker. In any case, it is frequent that the strength of the breeze during the hours of highest wind intensity can reach up to 4 on the Beaufort scale $(5.5-7.9 \mathrm{~m} / \mathrm{s}=20-28 \mathrm{~km} / \mathrm{h}$ ). The sea breeze develops as long as the thermal difference between sea temperature (SST, averaged sea surface temperature) and land temperature (LST, averaged land surface temperature) is maintained. Under sea-breeze conditions in the bay of Palma, Grau et al. [24] found that the difference between LST and SST is greater than $5{ }^{\circ} \mathrm{C}$ during the central hours of the day. 
It should also be noted that daytime breezes generated on the coasts operate with some simultaneity, so that breeze episodes generated in different and opposite coastal areas can coexist [25]. As a consequence of this spatial organization of breezes in Mallorca, the island is separated by at least two main breeze regimes-one northern and one southern-whose border is located in the central area. This general scheme has been verified by the numerical and experimental-theoretical models tested by Ramis et al. [26] and Ramis and Romero [21].

\section{Environmental Significance of Sea Breezes}

\subsection{Climatic Effects}

In places where they blow very often and regularly, breezes are true 'wind clocks' and have a marked influence on the hourly, daily and annual wind regime. As a result, the first environmental consequence of this phenomenon is climatic, and specifically windrelated. Firstly, the more or less regular and persistent presence of breeze episodes in Mallorca determines and modifies the general scheme of its annual wind regime, and causes the regime of each locality to acquire its own characteristics, which is especially true in coastal locations.

Although the present article does not aim to select, count and statistically analyze breezy days, it must be said that there is abundant scientific literature on the method used for selecting genuine sea-breeze days to distinguish them from those that are not. Most authors [27-32], without relinquishing the combined application of alternative validation filters (cloudiness, hours of insolation, increase in relative humidity, duration of the sea flow), emphasize, even as the only selective criterion, the identification of a rapid change in direction and wind speed. This change takes place sometime in the morning, when the difference between the land and sea temperature $(\Delta T)$ is positive. In addition, there are essential atmospheric requirements for the breeze to blow: synoptic regional conditions must be stable, so there must be a weak pressure gradient at surface level and a weak large-scale flow $[27,30,31]$. The breeze blowing is also evidenced by a sudden increase in onshore wind velocity, or a sudden decrease in temperature plus an increase in humidity.

In Mallorca, being an island, the change in wind direction occurs differently depending on the location. In the observatories located around the southern coasts, before the breeze blows, the wind direction is from the first quadrant (i.e., offshore winds), but when the breeze blows, during the daytime, the direction changes to the third quadrant, usually from the southwest (Son Ferriol). On the other hand, at observatories located around the northern coasts, the wind direction is initially from the second or third quadrant (also land wind), and the sea breeze changes direction to the first quadrant, usually from the northeast and east (Sa Pobla).

To verify this, Figure 3 represents a map of Mallorca with the annual wind direction frequency roses of five meteorological stations at 1 p.m. UTC-i.e., the time when breezes should have reached their maximum strength (data prior to 1 April 2014 are shown in solar time). The data from these stations correspond to the period 2004-2017 and come from the Sistema de Información Agroclimática para el Regadío (Agro-climatic Information System for Irrigation, SIAR). In Spain, this system has a network of agroclimatic stations designed to capture, record and transmit the data needed to calculate the water demand of irrigated areas, referring to air temperature and humidity, solar radiation, rainfall, wind speed and direction. The same wind roses drawn on the map in Figure 3 are detailed in Figure 4, showing for each station the frequency distribution of occurrences of winds in each of 16 direction sectors $(\mathrm{N}=$ north, $\mathrm{NNE}=$ north-northeast, $\mathrm{NE}=$ northeast, etc.) and six wind speed classes for the given location and time period (14-year study period, 2004-2017). 
The represented relative frequency roses allow us to verify, on the one hand, the complexity of the wind regime in the island, and on the other hand, the influence of sea breezes in the annual wind regime of each locality, which acquires its own characteristics depending on its geographical location. The locations closer to or further from the coast have antithetical daytime wind patterns, so that in a breeze scenario, in the Bay of Palma (station IB04, Son Ferriol), the absolute predominance of SW and SSW frequencies at 1 p.m. is instrumentally verified ( $44.4 \%$ and $30.5 \%$ of days of the period analyzed, respectively) (Figure 4a), while in the plain of the opposite Bay of Alcúdia (station IB06, Sa Pobla) (Figure 4c), the circulation is mainly from the E, NE and NNE (30.8\%, 20.7\% and 14.5\%, respectively). The pre-coastal areas of the Llevant coast (station IB03, Manacor; station IB05, Felanitx) (Figure $4 \mathrm{~d}, \mathrm{e}$ ) have a more complex aerial regime, and the sea breeze develops there over a wider range of directions around the second and third quadrants: in Manacor, the SE (23.1\%), E (14.2\%), ESE (13.2\%) and SW (11.7\%) prevail, while in Felanitx, the SE (15.5\%), SSE (13.7\%) and SSW (13.6\%) prevail. On the other hand, the relative frequency rose of the Inca station (IB02) (Figure 4b) presents an axial symmetry, with a very well-defined NE-SW axis $(24.2 \%$ and $19.6 \%$, respectively), which means that the wind regime in this inland locality is alternatively influenced by the breeze patterns established in the south of the island (Bay of Palma) and in the north (Bay of Alcúdia), with a predominance of the latter (Table 1).

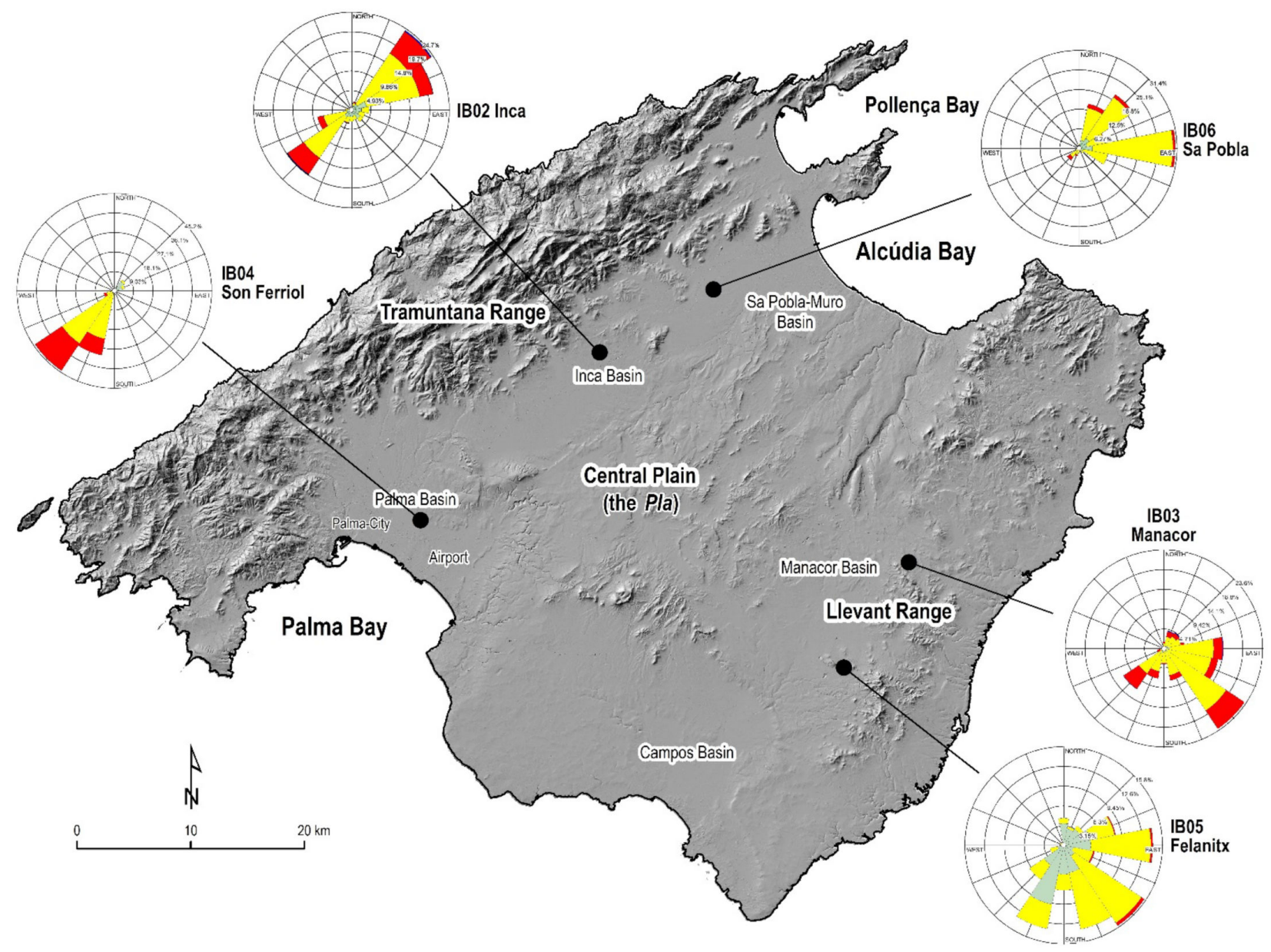

Figure 3. Location of the five weather stations analyzed, and respective wind frequency roses at the time of theoretical maximum sea-breeze intensity (June, July and August, 1 p.m.), for a 14-year study period (2004-2017). The polar charts with their corresponding legends are shown in detail in Figure 4. Percentages represent the frequency of wind direction. 

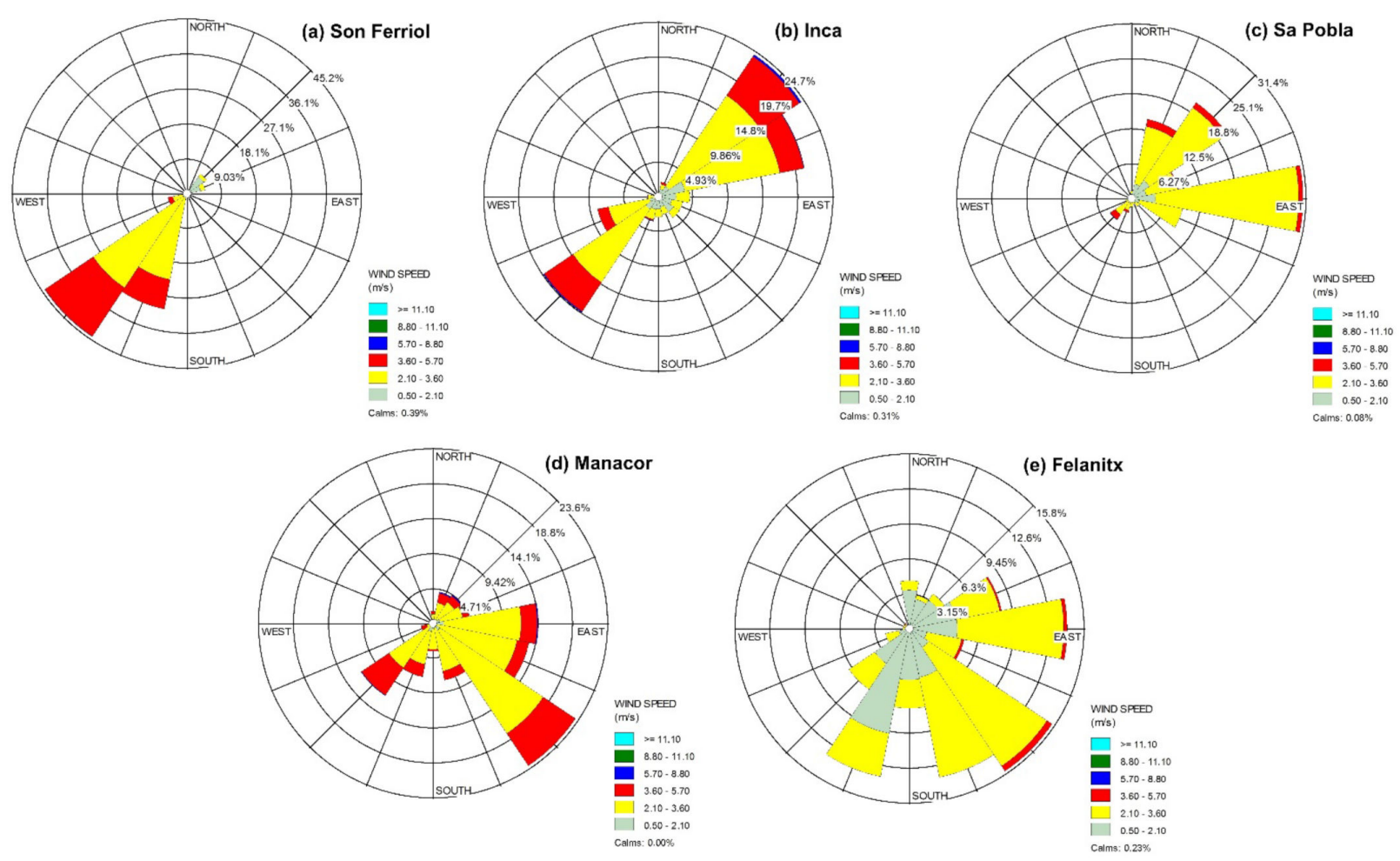

Figure 4. Polar bar charts of the relative frequency of wind direction $\left(^{\circ}\right)$ and wind speed $(\mathrm{m} / \mathrm{s})$, at the time of theoretical maximum sea-breeze intensity (June, July and August, 1 p.m.) for a 14-year study period (2004-2017) in five meteorological stations of the Sistema de Información Agroclimática para el Regadío (SIAR), Spain: (a) IB04 Son Ferriol; (b) IB02 Inca; (c) IB06 Sa Pobla; (d) IB03 Manacor; (e) IB05 Felanitx. Percentages represent the frequency of wind direction.

Table 1. Absolute (days) and relative (\%) frequency of sea-breeze direction $\left({ }^{\circ}\right)$ at the time of theoretical maximum wind intensity (June, July and August, 1 p.m.) for a 14-year study period (2004-2017) in five meteorological stations of the Sistema de Información Agroclimática para el Regadío (SIAR), Spain. Non-windy days at that time (calms) have not been counted.

\begin{tabular}{|c|c|c|c|c|c|c|c|c|c|c|}
\hline $\begin{array}{c}\text { Wind } \\
\text { Direction }\end{array}$ & $\begin{array}{l}\text { Num. Days } \\
\text { Son Ferriol }\end{array}$ & $\%$ & $\begin{array}{l}\text { Num. Days } \\
\text { Manacor }\end{array}$ & $\%$ & $\begin{array}{c}\text { Num. Days } \\
\text { Sa Pobla }\end{array}$ & $\%$ & $\begin{array}{c}\text { Num. Days } \\
\text { Felanitx }\end{array}$ & $\%$ & $\begin{array}{c}\text { Num. Days } \\
\text { Inca }\end{array}$ & $\%$ \\
\hline $\mathrm{N}$ & 9 & 0.7 & 22 & 1.7 & 18 & 1.4 & 56 & 4.4 & 7 & 0.5 \\
\hline NNE & 8 & 0.6 & 56 & 4.3 & 187 & 14.5 & 40 & 3.1 & 28 & 2.2 \\
\hline NE & 81 & 6.3 & 60 & 4.7 & 267 & 20.7 & 49 & 3.8 & 311 & 24.2 \\
\hline ENE & 64 & 5.0 & 65 & 5.0 & 111 & 8.6 & 109 & 8.5 & 270 & 21.0 \\
\hline $\mathrm{E}$ & 17 & 1.3 & 183 & 14.2 & 396 & 30.8 & 183 & 14.2 & 58 & 4.5 \\
\hline ESE & 9 & 0.7 & 170 & 13.2 & 121 & 9.4 & 65 & 5.1 & 46 & 3.6 \\
\hline SE & 15 & 1.2 & 297 & 23.1 & 24 & 1.9 & 199 & 15.5 & 47 & 3.7 \\
\hline SSE & 9 & 0.7 & 101 & 7.8 & 16 & 1.2 & 176 & 13.7 & 34 & 2.6 \\
\hline$S$ & 14 & 1.1 & 49 & 3.8 & 21 & 1.6 & 93 & 7.2 & 38 & 3.0 \\
\hline SSW & 391 & 30.5 & 95 & 7.4 & 34 & 2.6 & 175 & 13.6 & 46 & 3.6 \\
\hline SW & 570 & 44.4 & 151 & 11.7 & 61 & 4.7 & 85 & 6.6 & 252 & 19.6 \\
\hline WSW & 66 & 5.1 & 22 & 1.7 & 15 & 1.2 & 29 & 2.3 & 113 & 8.8 \\
\hline W & 5 & 0.4 & 5 & 0.4 & 1 & 0.1 & 8 & 0.6 & 21 & 1.6 \\
\hline
\end{tabular}


Table 1. Cont.

\begin{tabular}{|c|c|c|c|c|c|c|c|c|c|c|}
\hline $\begin{array}{c}\text { Wind } \\
\text { Direction }\end{array}$ & $\begin{array}{l}\text { Num. Days } \\
\text { Son Ferriol }\end{array}$ & $\%$ & $\begin{array}{l}\text { Num. Days } \\
\text { Manacor }\end{array}$ & $\%$ & $\begin{array}{l}\text { Num. Days } \\
\text { Sa Pobla }\end{array}$ & $\%$ & $\begin{array}{c}\text { Num. Days } \\
\text { Felanitx }\end{array}$ & $\%$ & $\begin{array}{l}\text { Num. Days } \\
\text { Inca }\end{array}$ & $\%$ \\
\hline WNW & 3 & 0.2 & 5 & 0.4 & 4 & 0.3 & 8 & 0.6 & 7 & 0.5 \\
\hline NW & 8 & 0.6 & 2 & 0.2 & 5 & 0.4 & 8 & 0.6 & 3 & 0.2 \\
\hline \multirow[t]{2}{*}{ NNW } & 14 & 1.1 & 5 & 0.4 & 6 & 0.5 & 3 & 0.2 & 3 & 0.2 \\
\hline & 1283 & 100.0 & 1288 & 100.00 & 1287 & 100.0 & 1286 & 100.0 & 1284 & 100.0 \\
\hline
\end{tabular}

The wind-speed frequency distribution plots for each station analyzed are shown in Figure 5 . In all these stations, the most frequent velocity range at 1 p.m. during the summer months (June, July and August) is between 2.10 and $3.60 \mathrm{~m} / \mathrm{s}$. This range dominates even more in the stations of Sa Pobla (73.8\%) and Manacor (68.9\%). It can also be said that at the Son Ferriol station, under the influence of sea breezes from the bay of Palma, winds reaching $5.7 \mathrm{~m} / \mathrm{s}$ are also relatively frequent. At this station, the average wind speed is 2.89 $\mathrm{m} / \mathrm{s}$. At the Inca station, it is $2.73 \mathrm{~m} / \mathrm{s}$, at Sa Pobla it is $2.55 \mathrm{~m} / \mathrm{s}$, at Manacor it is $3.00 \mathrm{~m} / \mathrm{s}$ and at Felanitx it is $2.09 \mathrm{~m} / \mathrm{s}$.

(a) Son Ferriol

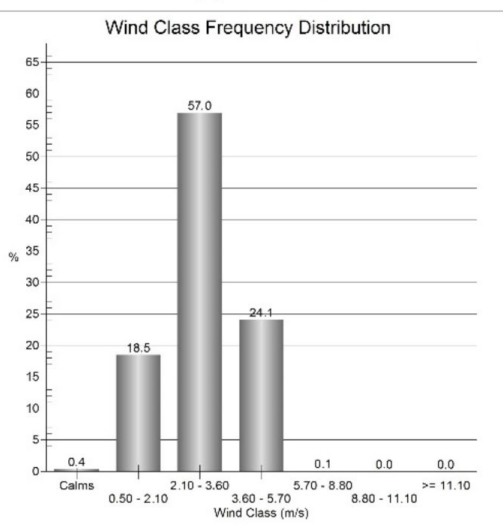

(b) Inca

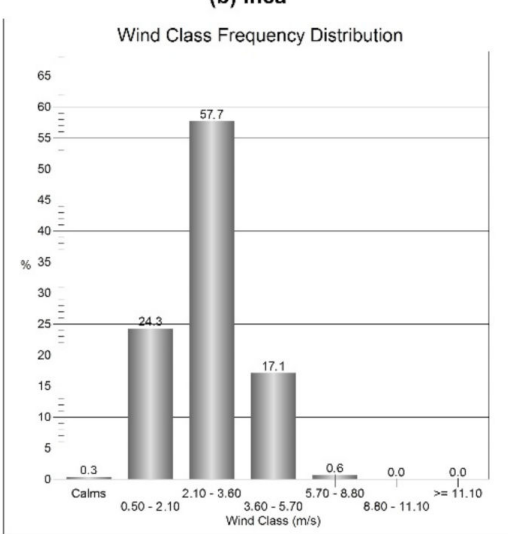

(c) Sa Pobla

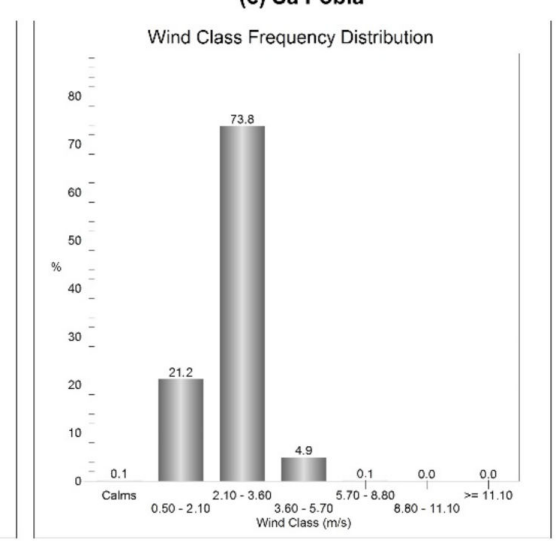

(d) Manacor

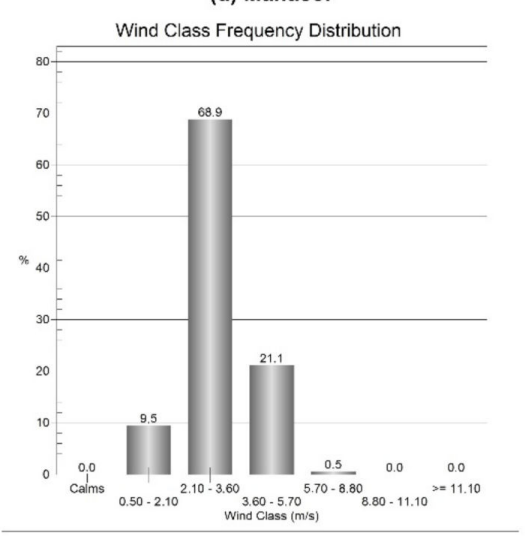

(e) Felanitx

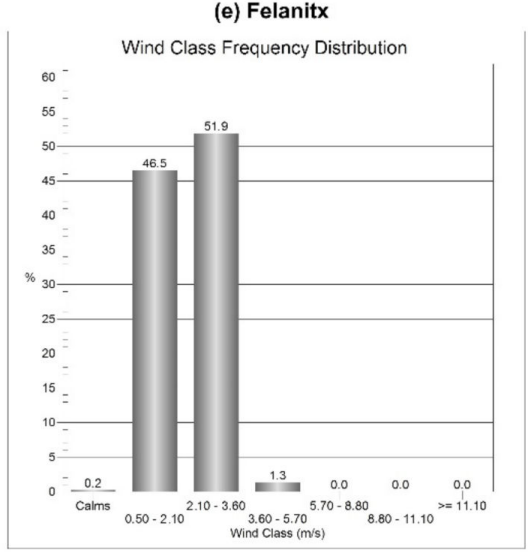

Figure 5. Bar charts of the wind-speed (m/s) class frequency distribution, at the time of theoretical maximum sea-breeze intensity (1 p.m.) for a 14-year study period (2004-2017) in five meteorological stations of the Sistema de Información Agroclimática para el Regadío (SIAR), Spain: (a) IB04 Son Ferriol; (b) IB02 Inca; (c) IB06 Sa Pobla; (d) IB03 Manacor; (e) IB05 Felanitx.

\subsection{Moisture and Precipitation}

In addition to the influence of breezes on the annual wind regime, there are also their effects on atmospheric humidity. From the time that maritime airflow ascends over the 
coastline and penetrates into the mainland, breeze fronts transfer moisture to the continental surfaces [33]. This directly affects not only evapotranspiration, but also has important repercussions on precipitation processes [34,35]. As in many other cases, in Mallorca, the wind acts as a vehicle for the displacement of large maritime air masses inland, so that in the meteorological records of the observatories located in areas relatively far from the coast, it is evident that the air properties respond to a previous contact with the sea.

The advance of the maritime air mass occurs in a manner reminiscent of a cold front, and is characterized by a sudden gust of wind, a drop in temperature and an increase in relative humidity. Under conditions of convective instability, the convergence of breezes in inland areas at low levels triggers the formation of micro-continental scale storms [22,35,36]. Guijarro and Heredia [37] identified an increase in the frequency of cloud-to-ground electrical discharges-lightning - in spring and summer, in inland areas of Mallorca and in the afternoon, coinciding with the aforementioned confluence of breezes. These summer storms are associated with cumuliform cloudiness of great interest for the forecasting meteorologist [38,39]. In relation to this, Ramis and Alonso [20] and AzorinMolina et al. [35] developed automatic cloud detection methods from satellite images, with which they identified convergence processes associated with the sea breeze in Mallorca (Figures 6 and 7). Alomar-Garau and Grimalt-Gelabert [23] described two models of spatial distribution of summer rainfall on the island, for which converging sea breezes act as a trigger: one that draws a transverse strip oriented from southeast to northwest, and which is strictly related to the theoretical main line of convergence of breezes described by Jansá and Jaume [18], and another one, more variable, by which the rainfall is focused at some central point of the island near the aforementioned line.

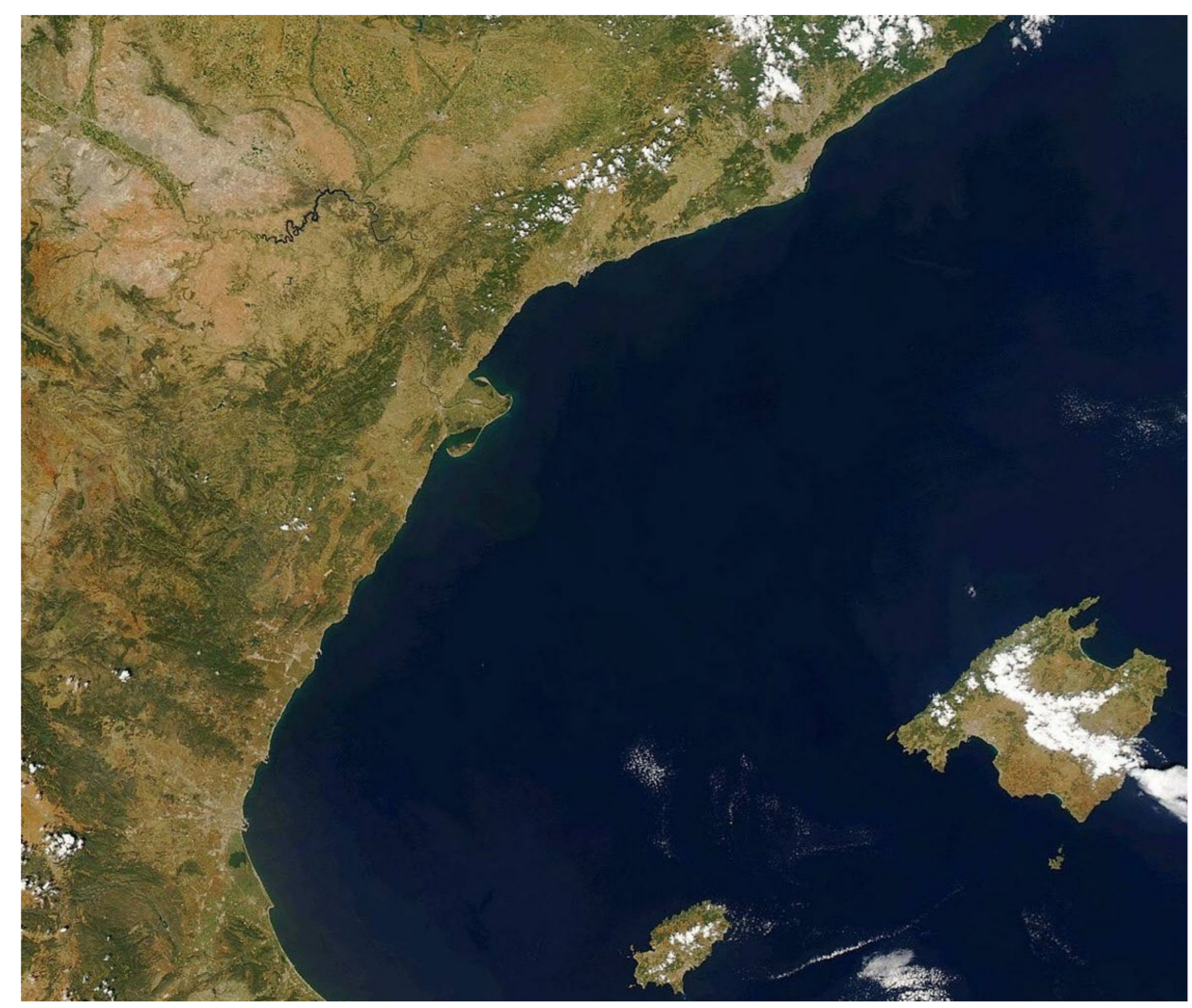

Figure 6. NOAA image (Sensor Modis, canals 1-4-3) of 1 June 2009 at 1320 UTC, focusing on the Balearic Sea and the littoral area of Catalonia and Valencia. On the island of Mallorca (bottom-right), a dense layer of cumulus completely covers the central part of the island, conforming to the theoretical sea-breeze convergence area. The cloudiness extends to the east, driven by winds from the west in the middle and upper layers of the atmosphere. 


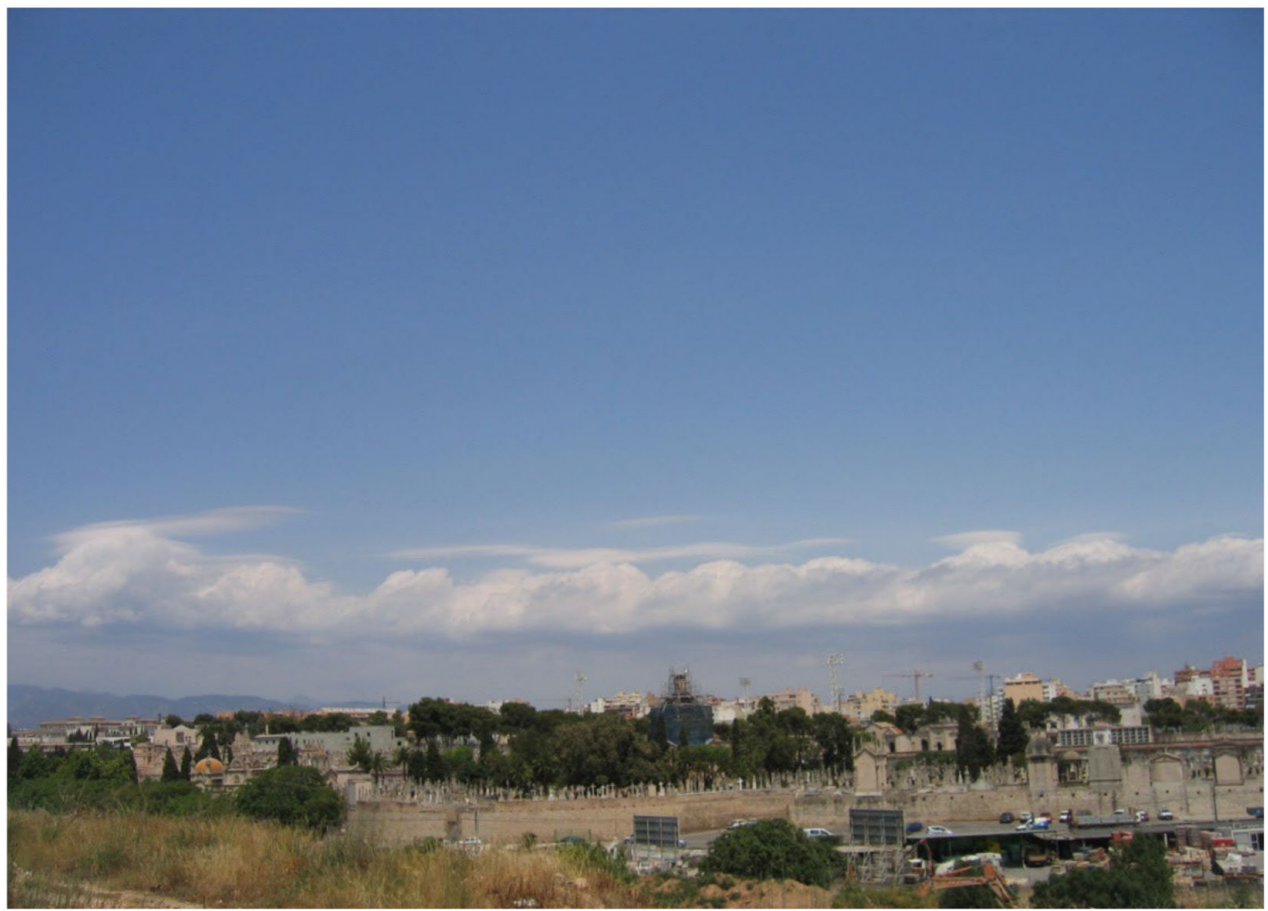

Figure 7. Cumuliform convective cloudiness due to convergence of breezes over the central area of Mallorca, from the city of Palma looking north, on 14 June 2005. In the background, inland, a well-defined line of cumulus $(\mathrm{Cu})$ crosses the center of the island from west to east. Photo: $\mathrm{G}$. Alomar-Garau.

Regarding summer rainfall, in Mallorca, maximum instability occurs during the end of warm period, when sea surface temperature (SST) reaches its highest values and some cold air advections affect the Western Mediterranean. Thus, from March to August, the lightning density is higher in the inland area than in the maritime area, mainly because of the most important diurnal heating being of the terrestrial surface rather than the maritime surface, and due to the sea breeze and its convergence area in the inner part of the island, that with some particular conditions brings on the development of summer storms. A monthly analysis [40] showed a variation in August and September thunderstorm activity, mainly in terrestrial areas. August's percentage of activity tends to grow as we move to the inner part of Mallorca, and September's percentage tends to decrease. When analyzing the innermost region, where the distance to the shoreline is greater than $15 \mathrm{~km}$, August, with $33.1 \%$, accumulates a greater number of instances of lightning than September (32.7\%). Hourly analysis shows an important increase in diurnal thunderstorm activity as we move to the inner part of the island, reaching a peak of $56 \%$ of the total activity for the 10-14 UTC period in the innermost region. At the same time, nighttime activity tends to decrease. As we move into the maritime zone, nighttime activity tends to grow, and diurnal activity tends to decrease.

\subsection{Temperature and Climate Comfort}

The effect of sea breezes in reducing the maximum thermometric values is wellknown, relieving the heat to a certain extent. It has been said that insolation heat stroke has a euphoric effect and incites optimism [41,42]. In the same way, breezes provide a climatic comfort-added to that already provided by the Mediterranean climate-which explains the development of tourism in many areas of the Balearic and Mediterranean coast in general. This is because light winds (up to $19 \mathrm{~km} / \mathrm{h}$ ) are part of the catalog of weather types conducive to tourism [43]. Additionally, due to the effect of continentality, the thermal oscillation in Mallorca increases inland and is more pronounced in summer 
than in winter. Even so, under sea-breeze conditions, the isotherms are noticeably curved towards the central areas of the island, due to the moderating thermal effect of the breezes.

In the same way, wind is a determining factor in measuring the thermal comfort of cities, and hence certain urban plans of the late nineteenth century in coastal cities such as Palma reproduced the hygienist arguments of the time to draw the streets perpendicular to the coastline, and thus allow the healthy circulation of breezes [44]. Climatic comfort is understood as the existence of combinations of environmental parameters (temperature, humidity, radiation and wind) that do not generate stress in the human body. The limits of this comfort are very narrow. According to Olgyay's human climatic comfort criteria, they are limited to a temperature range between $23.9^{\circ} \mathrm{C}$ and $29.5^{\circ} \mathrm{C}$, and a relative humidity range between $20 \%$ and $70 \%$ [45]. Above the maximum allowable thermal value, comfort can be achieved by the cooling effect of wind, as the movement of air increases the dissipation of energy by evaporation or convection, provided that the skin temperature is lower than the air temperature. However, when temperatures are above $40^{\circ} \mathrm{C}$, wind increases the heat sensation.

Under urban heat island conditions, sea breezes cool the hot city environment during the summer, but the urban morphology can decrease wind speed, increasing discomfort due to humid heat. Although the thermal increase decreases the relative humidity, this decrease is hardly noticeable because maritime air currents keep the humidity in. In the coastal city of Palma, Alomar and Llop [46] noted urban heat island intensities of up to $4.9^{\circ} \mathrm{C}$ in July, which may contribute to overheating the breeze along its urban route through neighborhoods that are not strictly maritime. In contrast, in more open areas close to the sea or in higher-level housing, sea breezes have a cooling effect, which often moderates summer heat.

According to data from the Spanish Agencia Estatal de Meteorología (AEMET), the normal climatological values at Palma airport for the period 1981-2010 indicate that the annual average of maximum daily temperatures is $22.4^{\circ} \mathrm{C}$, and in August it is $31.3{ }^{\circ} \mathrm{C}$. It is also common for the rural village of Sa Pobla, in the north of Mallorca, to reach maximum temperatures of over $30^{\circ} \mathrm{C}$ in summer. This happens especially when sea breezes blow only from the southern coasts and not from the north, so that they have to travel a long distance to reach this locality, thus having more time for their temperature to increase [47]. When the breezes do reach Sa Pobla, they play a cooling role and the maximum temperature decreases. The main effect of the breeze in relation to thermal comfort is to prevent temperatures in the central hours of the day from reaching extreme values. To illustrate this point, Figure 8 describes the time evolution of temperatures at the Son Ferriol weather station, placed near the coast of the Bay of Palma, between June 2 and 9 2020. It can be seen how the irruption of the sea breeze (June 2, 3, 6, 7 and 9) results in an interruption of the temperature rise as the day progresses. This means that sea breezes strongly contribute to moderating heat stress in any environment. In contrast, on days with no sea breezes (June 4, 5 and 8), the normal temperature rise is not interrupted. The sea breeze on June 9 exceeded $3 \mathrm{~m} / \mathrm{s}$ speed (about 6 knots), blowing stronger than on previous days. This higher speed resulted in lower temperatures during the early afternoon, due to the cooling effect of the wind. Since, on the hottest days of the year, inside cities the thermal sensation is of additional 'heat', designing streets and buildings to be ventilated by daytime breezes can be considered a good urban planning practice. 


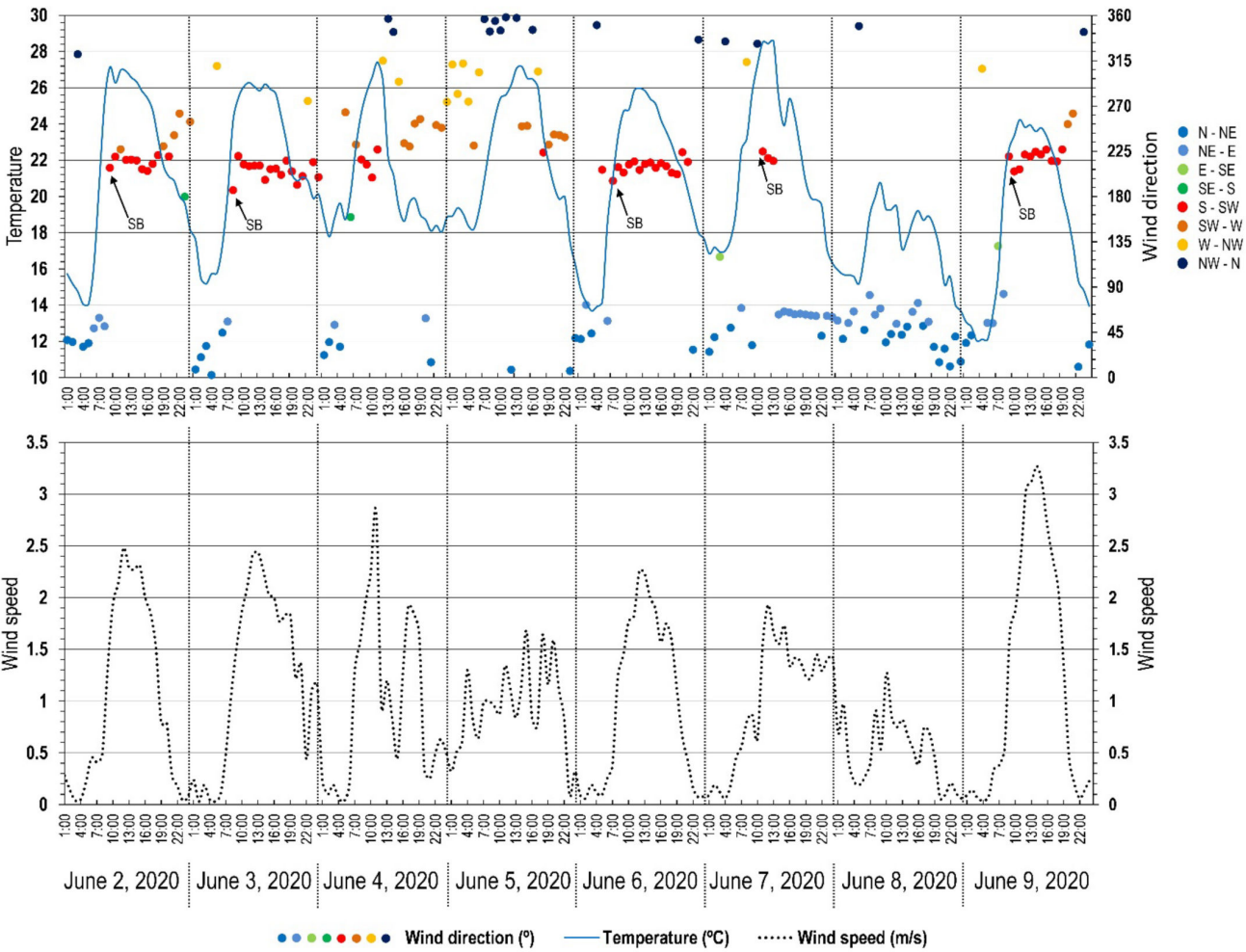

Figure 8. Daily time-series of temperature, wind direction and wind speed at the Son Ferriol weather station (Mallorca) between June 2 and 9, 2020. At times when the sea breeze typically blows from the S or SW (red colored circles), the temperature rise slows down and stabilizes temporarily. June 4 and 5 were days with no sea breezes. June 8 was a day with general northerly winds. In the top plot, arrows marked SB indicate the starting time of the sea breeze in the bay of Palma and therefore at the station.

\subsection{Transport and Diffusion of Pollutants}

Breezes actively collaborate in the transport of atmospheric pollutants. The dynamics of atmospheric aerosols, and ultimately the evolution of their concentration, are examples of the chemical effects of breezes, as corroborated by Millán et al. [48] in a study characterizing the dynamics of these pollutants in the Mediterranean basin. The effects of the breeze as a factor both in air renewal and air quality, and in the transport and distribution of pollutants, have been extensively studied [8] to reach a reliable conclusion: breezes disperse and transport the pollutants emitted within the atmospheric layer in which this circulation is formed, but do not necessarily clean it. On the contrary, sea breezes cause a small subsidence inversion in coastal areas, which can lead to the spraying of pollutants once they have been trapped within the layer topped by the inversion [49].

In winter, the not-infrequent situations of anticyclonic atmospheric stability in the western Mediterranean region induce stagnation of air masses and consequent episodes of urban pollution. In addition, within the atmospheric boundary layer, there is a vigorous mixing of the air which favors the chemical reactions of pollutants, creating new chemical compounds that translate into new pollutants. However, in situations of strong and wellestablished breezes, these effects are clearly attenuated.

In any case, breeze circulation activates the pollutant recirculation processes. If insolation is high, pollution may be of photochemical origin, and it is then that ozone records become important. In this sense, if anthropogenic activities cause tropospheric ozone concentrations to rise to low levels, the aerial behavior of this gas depends on the atmospheric dynamics at the site, and therefore on the influence of a possible coastal breeze's circulation established at the locations where the gas is generated. In Mallorca, Romero and Ramis [50] numerically simulated the evolution of an eventual emission of atmospheric pollutants 
produced in the north of the island, based on the hourly behavior of the sea breeze, and pointed out that the line of confluence of coastal flows typically formed in the central part of the island limits the expansion of pollutants towards the south, and diverts their transport towards the Tramuntana mountain range, which acts by blocking the pollutants.

\subsection{Life Cycle of Plants and Animals}

From a biological and agroclimatic point of view, wind is a determining factor in a multitude of vital processes. It intervenes in the distribution and transport of birds and flying insect species, as well as in the spread of pollen and transport of seeds over long distances, dispersing the spores and pollen of anemophilous plant species (wind-pollinated, to differentiate them from entomophilous species, pollinated by insects). In Mallorca, Vives et al. [51] showed that certain local sea breeze conditions affect the cross-fertilization of maize in crop fields oriented according to the direction of the breeze. In this sense, the aerological regime of a place determines, in part, its yield in the cultivation of certain plants.

The presence of hardwood forests in the center of the island, in contrast to the more xerophytic vegetation of the coasts, responds mainly to edaphic factors, not to rainfall in inner areas of Mallorca. Nevertheless, certain traditional agricultural practices, such as the production of summer vegetables in the central plain, can be favored by eventual summer rains. An insular landrace of tomato (Solanum lycopersicum), the so-called "tomàtiga de ramellet", is particularly resistant and adapted to summer drought [52], but its growth benefits from summer storms favored by the convergence of sea breezes inland.

Morphological analyses of some elements of nature used as climatic indicators of local winds are not new. For instance, tree inclination has been used to determine decadal variations in wind direction and intensity in places $[53,54]$. This inclination constitutes a historical record of the prevailing wind direction, usually in coastal locations where the air arrives laden with marine aerosols. Likewise, the limiting effect of wind on vegetation growth causes plants to protect themselves by adopting sclerophyllous structures to prevent the plant's transpiration rate from exceeding the rate of water absorption by the roots. This results in a morphological modeling action in trees, shrubs and scrubs. Wind interference on vegetation growth is basically due to the influence of the salt spray transported by the force of the moving air. Breezes do not cause sufficient swell to result in the formation of salt spray that could interfere with the development of vegetation. In Mallorca, this is rather affected by the general wind regime, especially incoming winds from the north or west, and Mediterranean atmospheric disturbances.

Moreover, light breeze conditions seem to be decisive in the recurrent blooms of the toxic algae Alexandrium taylori near the coast in summer conditions, as demonstrated by Basterretxea et al. [55], studying a case in the bay of Santa Ponsa, in Mallorca's southwest. It is, by the way, a curious fact that there is a flowering plant, Erigeron glaucus, whose popular name is "Sea Breeze" [56], an herbaceous plant of the daisy family, which is reputed to drive away fleas. It usually grows on the southern coasts of Great Britain, so it is ideal for coastal and beach gardens.

\subsection{Coastal Geomorphology}

Beach-dune systems can be interpreted in wind terms, not only because the wind regime is one of the factors involved in the dynamics of the dunes - controlling the subaerial dynamics-but also because in these systems, the predominant wind direction can be observed. Around seventeen beach-dune systems have been developed in Mallorca, such as Es Comú de Muro, Sa Mesquida, Son Real and Sa Canova in the north of the island; Es Trenc or Es Carbó in the south; and s'Amarador in the southeast, located in the Natural Park of Mondragó. These systems are located in most coastal inlets, taking advantage of the prevailing winter and autumn winds (north and west) and summer (sea breezes), although they are characterized as being a confluence of geological, climatic and biological factors.

The formation of these dunes is due to aeolian processes of erosion (deflation and abrasion), transport (displacement of individual grains or of 'migratory' dune morpholo- 
gies) and sedimentation of materials [57]. The critical wind speed needed to move sandy sediment is $4.5 \mathrm{~m} / \mathrm{s}$ [58], which shows the capacity of breezes to mobilize it, and ultimately its role in beach dynamics during periods of low-energy waves [59,60].

Moreover, Ponce de León and Orfila [61] carried out a study of sea breezes and their impact on the wave field around Mallorca Island. The observations confirm a modification of the hindcasted wave propagation direction for breeze speeds higher than $7.5 \mathrm{~m} / \mathrm{s}$. These breezes induce changes in the incident wave field in late morning or early afternoon, increasing wave height, shortening the mean wave period and changing the wave propagation direction, according to the sea breeze. In areas where the sea breeze reigns (Alcúdia Bay to the north and Palma Bay to the south), its effects on the coastal dynamics are sizeable. It is concluded that the Weather Research and Forecasting-WRF-wind fields model properly depicts the local land-sea breezes around the island of Mallorca: the strength of the sea breezes in Alcúdia Bay during the day is greater, and they have a longer duration than in Palma Bay.

\section{Cultural, Socioeconomic and Territorial Significance}

Sea breezes have a notable influence on human activities, a circumstance that has been explored very little. To begin with, in many parts of the world, the determinations of the breezes are of such magnitude that the phenomenon is manifested in the language and dialect, through the popular fixation of a proper name that describes it. In the Catalan-speaking Mediterranean territories, the sea breeze takes the local terms "marinada" (Catalonia), "embatà del migdia" (Valencia) and "embat" (Mallorca), representing three exemplary cases of eolionymy. The local cooling afternoon sea breeze in southwest Australia is named the 'Fremantle doctor' [62]. When the breeze is named in a distinctive way, it means that the phenomenon is perceived to be of great importance and significance.

One of the most obvious influences of breezes on human working systems is that of the energetic exploitation of wind, both in the past and in the present (modern wind farms for electricity production are a constant feature in many developed countries around the world). In fact, local winds are one of the factors that explain the selective location of certain agricultural infrastructures in many regions of the Mediterranean and the world. In Mallorca, until the arrival of mass tourism in the mid-twentieth century, the conformation of the agricultural space was accompanied by the development of agricultural fields in which windmills and threshing-floors were massively deployed. Windmills in Mallorca are of two types: flour windmills, and windpumps used to extract water from aquifers and irrigate crops. In the Mediterranean, the construction of threshing floors for separating the chaff from the grain has been documented at least since Homer (8th century B.C.). From the most remote antiquity onwards, the threshing and winnowing of barley were carried out not only in places strategically selected to place threshing floors, but also taking advantage of the coincidence of the threshing work with the time when the breezes were more likely and regular.

Both in the case of threshing floors and of windmills, their geographic location and topographical placement are justified by the need to maximize their efficiency and profitability. The main factor of this placement is the quantity and quality of available eolian recourses, since if there is no wind, grains cannot be ground, and nor can they be obtained through the threshing floors. Alomar-Garau and Grimalt-Gelabert [63] tested a novel method to recreate and model the wind scenario of Mallorca at a time when neither instrumental nor meteorological data were available. The method was based on the inspection of aerial photographs from 1956 to geolocate and map the threshing floors where the ears of wheat used to be threshed and winnowed in summer. Analyzing and using these threshing floors as an ethnographic wind proxy made it possible to draw a map of wind directions on an island scale. This map reconstructs the spatial arrangement of the sea breezes in the island.

With regard to windmills, they are constructions directly created to take advantage of the kinetic energy of the wind and convert it into mechanical energy in order to grind the 
grain. This is why windmill sites look for places where ventilation is constant, or at least regular. In Mallorca, this constancy and regularity is offered by the summer sea breezes, and as a consequence, flour windmills are located in elevated places to better capture the breeze, or in front of the coast (in the rural villages and cities of Mallorca, these places are known as "molinars"). Windpumps do not have the same location as flour windmills, since their function is different, and they are located on the plains open to the sea breeze, near the coast. This way it is possible to draw a map of the wind potential of a territory by observing the geographical location of these infrastructures.

Although nearly all are derelict or in disrepair, windmills in Mallorca are ubiquitous and visually striking in many areas of the island [64,65]. As many as 818 old flour windmills [66] and 2445 windpumps have been inventoried, with almost all of the latter (92.3\%) being located in the three main areas of intensive agriculture: the plain or basin of Palma in the south, the plain of Sa Pobla-Muro in the north and the plain of Campos in the south. These areas are always coastal and are therefore well ventilated by the corresponding sea breezes (Figure 9).

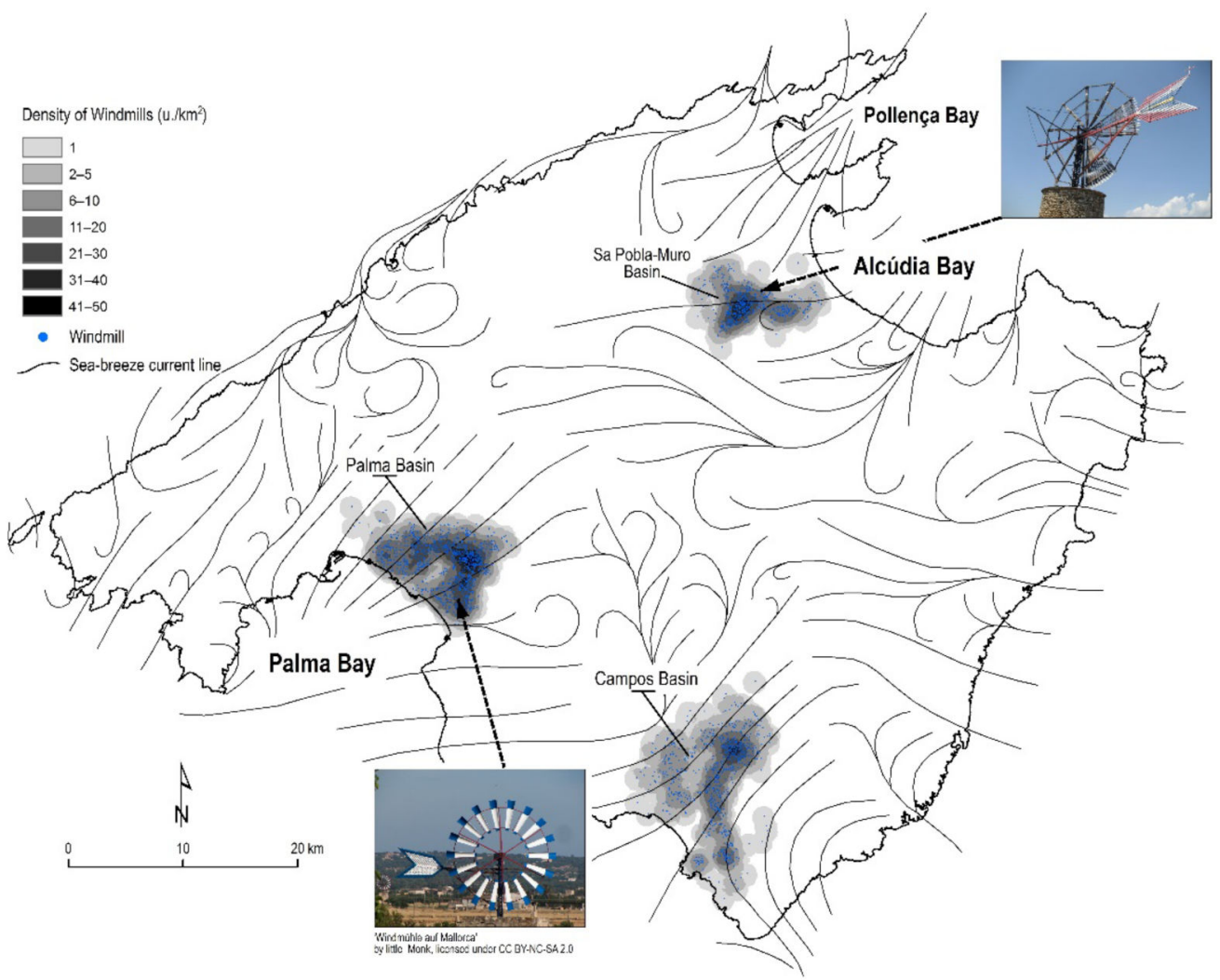

Figure 9. Location of windpumps in Mallorca. Curved lines show the common direction of the coastal breezes according to Jansá and Jaume [18], penetrating inland. Two photos show typical windmills of the plains of Palma and Sa Pobla-Muro.

From a social point of view, the recreational use of the sea breeze is also significant, conditioning the practice of sports such as windsurfing, kitesurfing and all types of sailboats in certain coastal hot spots. To these sports we can add surfing and paragliding. We must also include the boats that participate in official sports competitions such as the King's Cup sailing competition, which in summer uses the Bay of Palma as a regatta course precisely because of its wind aptitude for sailing: constant, benevolent winds that are easy to predict. In the case of surfing, whose practice depends on the prevailing swell, the breeze is considered a short-period, low-energy sea wind, which 'fouls' the swell and eliminates its effectiveness in generating low-height, low-energy coastal waves, degrading the surf. The sea breeze fetch (the distance over which the wind blows in a single direction) is very 
short, only a few kilometers long, so under sea breeze conditions a few kilometers away from the coast there is no onshore wind at all. When the sea breeze starts, its fetch extends only a little way off the coast, but as the strength of the breeze increases, the fetch extends further offshore until it reaches a maximum, although this rarely exceeds about $15 \mathrm{~km}$.

The vertical forcing of the air produced by breeze fronts and orographic air ascents is also used for the practice of paragliding, which follows the same flight rules used by certain gliding birds, and which is evidence of the existence of a thermal bubble of air rising from the ground.

On the other hand, the strategic geographical location of Palma's airport (Son Sant Joan), close to the coast, facing the wide bay, responds mainly to a climatic cause focused on the breeze regime. The SW breezes generated in the bay of Palma are responsible for the SW-NE orientation of the runways, because airplanes need a headwind both for takeoff and landing. Therefore, the coastal breezes of the bay regulate the runway time changes, which are decided in the control tower. Runway length also depends on the properties of the air near the ground. The density of the air decreases as it becomes warmer and more humid, and also decreases as the altitude increases. For this reason, the lower the air density on runways is, the higher the speed of the aircraft must be to take off and fly up, so in warmer places—or in airports located at elevations above $1000 \mathrm{~m}$-you need longer runways so that larger airplanes can reach the needed speed in order for take off.

\section{Conclusions}

The sea breeze is an atmospheric phenomenon widely represented in the areas of the world with a land-sea border. This phenomenon has outstanding and diverse environmental effects along the coast and in adjacent inland regions. Therefore, reducing breezes to the common category of "variable light winds" is as ambiguous as it is simple, and masks the significance of a phenomenon that moves masses of maritime air over tens of kilometers, eliminating slope winds and forming convective chimneys, sometimes causing storms. This is why sea breezes can be considered a specific feature that determines climate and weather on a local scale. They also have diverse effects on different human activities.

On the island of Mallorca, the breeze system acquires prototypical characteristics of frequency and intensity. In addition to episodes with high occurrence values, there is the simultaneity with which these thermally induced winds operate, generated in different and geographically opposed coastal areas: sea breezes flow simultaneously from the north, south and east coasts of the island, generating typical convergence zones inland. Mallorca, especially during the summer season, is uniquely subjected to the influence of a breeze system whose spatial and temporal scope includes and conditions all spheres of human settlement: first, the environmental sphere-the breeze system has major bioclimatic, agroclimatic, chemical, climatic and meteorological effects; second, the territorial spherethe breeze has historically conditioned the location, distribution and design of agricultural, architectural and tourist infrastructures, whose spatial organization can be interpreted in a wind key; third, the economic and social sphere-the breeze has influenced traditional agricultural and fishing activities, and is now influencing sports activities related to the sea; and fourth, the cultural sphere-the breeze has been reflected in local popular culture. All this raises the need to observe the breeze phenomenon as an element whose repercussions transcend the atmospheric sphere and manifests itself territorially, and shapes a wind and energy landscape that deserves further research. It is important to continue improving our understanding of sea breezes, their impact and potential benefits, since a large part of the human population lives in major cities in coastal areas.

Author Contributions: Conceptualization, G.A.-G. and M.G.-G.; methodology, G.A.-G. and M.G.-G.; formal analysis, G.A.-G. and M.G.-G.; investigation, G.A.-G. and M.G.-G.; data curation, G.A.-G.; writing—original draft preparation, G.A.-G.; writing—review and editing, G.A.-G. and M.G.-G. All authors have read and agreed to the published version of the manuscript.

Funding: This research received no external funding. 
Institutional Review Board Statement: Not applicable.

Informed Consent Statement: Not applicable.

Data Availability Statement: Wind instrumental data were provided by the Sistema de Información Agroclimática para el Regadío (SIAR), from their website at http://www.siar.es (accessed on 1 October 2021).

Acknowledgments: We sincerely thank the anonymous reviewers for provided helpful comments on earlier drafts of the manuscript.

Conflicts of Interest: The author declares no conflict of interest.

\section{References}

1. World Meteorological Organization (WMO). International Meteorological Vocabulary; No. 182; WMO: Geneva, Switzerland, 1992.

2. Simpson, J.E. Sea Breeze and Local Wind; Cambridge University Press: New York, NY, USA, 1994.

3. Miller, S.T.K.; Keim, B.D.; Talbot, R.W.; Mao, H. Sea Breeze: Structure, Forecasting, and Impacts. Rev. Geophys. $2003,41,1011$. [CrossRef]

4. Kiyota, T.; Kiyota, N. A study on the influence of land and sea breeze on air temperature in a wide area of Hiroshima in the summer season. J. Environ. Eng. AIJ 2005, 70, 45-51. [CrossRef]

5. Zhou, Y.; Guan, H.; Huang, C.; Fan, L.; Gharib, S.; Batelaan, O.; Simmons, C. Sea breeze cooling capacity andits influencing factors in a coastal city. Build. Environ. 2019, 166, 106408. [CrossRef]

6. Anjos, M.; Lopes, A.; Lucena, A.J.d.; Mendonça, F. Sea Breeze Front and Outdoor Thermal Comfort during Summer in Northeastern Brazil. Atmosphere 2020, 11, 1013. [CrossRef]

7. Yoshida, A.; Yasuda, R.; Kinoshita, S. Mobile Observation of Air Temperature and Humidity Distributions under Summer Sea Breezes in the Central Area of Osaka City. Atmosphere 2020, 11, 1234. [CrossRef]

8. Papanastasiou, D.K.; Melas, D. Climatology and impact on air quality of sea breeze in an urban coastal environment. Int. J. Climatol. 2009, 29, 305-315. [CrossRef]

9. Kingsmill, D.E. Convection Initiation Associated with a Sea-Breeze Front, a Gust Front, and Their Collision. Mon. Weather. Rev. 1995, 123, 2913-2933. [CrossRef]

10. Strickler, M.W. Sea-Breeze Fronts and Their Role in Convective Initiation; North Carolina State University: Raleigh, NC, USA, 2003.

11. Neumann, J. The sea and land breezes in the classical Greek literature. Bull. Am. Meteorol. Soc. 1973, 54, 5-8. Available online: https:/ / www.jstor.org/stable/26254579 (accessed on 5 October 2021). [CrossRef]

12. Zerefos, C.; Solomos, S.; Melas, D.; Kapsomenakis, J.; Repapis, C. The Role of Weather during the Greek-Persian "Naval Battle of Salamis" in 480 B.C. Atmosphere 2020, 11, 838. [CrossRef]

13. Redaño, A.; Cruz, J.; Lorente, J. Main features of the sea breeze in Barcelona. Meteorol. Atmos. Phys. 1991, 46, 175-179. [CrossRef]

14. Physick, W.L.; Byron-Scott, R.A. Observations of the sea breeze in the vicinity of a gulf. Weather 1977, 32, 373-381. [CrossRef]

15. Sumner, G.N. Sea breeze occurrence in hilly terrain. Weather 1977, 32, 200-208. [CrossRef]

16. Archduke Ludwig Salvator von Österreich-Toskana. Las Baleares por la Palabra y el Grabado; Caja de Baleares Sa Nostra: Palma, Spain, 1871; pp. 1980-1993.

17. Weyler, F. Topografía Físico-Médica de las Islas Baleares y en Particular de la de Mallorca; Imprenta de Pedro José Gelabert: Palma, Spain, 1854.

18. Jansá, J.M.; Jaume, E. The sea breeze regime in the Mallorca Island. Rev. Geofis. 1946, 19, 304-328. (In Spanish)

19. Miró-Granada, J.; Josep, M. Jansá Guardiola. Notas biográficas. Territoris 1998, 1, 17-45.

20. Ramis, C.; Alonso, S. Sea-breeze convergence line in Majorca. A satellite observation. Weather 1988, 43, 288-293. [CrossRef]

21. Ramis, C.; Romero, R. A first numerical simulation of the development and structure of the sea breeze on the island of Mallorca. Ann. Geophys. 1995, 13, 981-994. [CrossRef]

22. González, J.; Heredia, M.A. Convección por brisa en Mallorca. In V Simposio Nacional de Predicción del Instituto Nacional de Meteorología; Instituto Nacional de Meteorología: Madrid, Spain, 2001; Available online: http:/ /hdl.handle.net/20.500.11765/4688 (accessed on 5 October 2021).

23. Alomar-Garau, G.; Grimalt-Gelabert, M. Precipitaciones de verano y régimen de brisas en Mallorca (Summer rainfalls and breeze regime in Mallorca). In Clima, Sociedad y Medio Ambiente; Cuadrat, J.M., Saz, M.A., Vicente, S.M., Lanjeri, S., de Luis, M., González-Hidalgo, J.C., Eds.; Asociación Española de Climatología: Zaragoza, Spain, 2006; pp. 1-11.

24. Grau, A.; Jiménez, M.A.; Cuxart, J. Statistical characterization of the sea-breeze physical mechanisms through in-situ and satellite observations. Int. J. Climatol. 2021, 41, 17-30. [CrossRef]

25. Alomar-Garau, G.; Grimalt-Gelabert, M. Un modelo de simultaneidad de brisas marinas en Mallorca. In Cambio Climático Regional y sus Impactos; Sigró, J., Brunet, M., Aguilar, E., Eds.; Publicaciones de la Asociación Española de Climatología (AEC), Serie A: Tarragona, Spain, 2008; pp. 3-14.

26. Ramis, C.; Jansà, A.; Alonso, S. Sea breeze in Mallorca: A numerical study. Meteorol. Atmos. Phys. 1990, 42, 249-258. [CrossRef]

27. Steyn, D.G.; Faulkner, D.A. The climatology of sea breezes in the lower Fraser Valley. B. C. Climatol. Bull. 1986, $20,21-39$.

28. Banfield, C.E. The frequency and surface characteristics of sea breezes at St. Johns, Newfoundland. Climatol. Bull. 1991, 25, 3-20. 
29. Gustavsson, T.; Lindqvist, S.; Borne, K.; Bogren, J. A study of sea and land breezes in an archipelago on the west coast of Sweden. Int. J. Climatol. 1995, 15, 785-800. [CrossRef]

30. Borne, K.; Chen, D.; Núnez, M. A method for finding sea breeze days under stable synoptic conditions and its application to the swedish west coast. Int. J. Climatol. 1998, 18, 901-914. [CrossRef]

31. Furberg, M.; Steyn, D.G.; Baldi, M. The climatology of sea breezes on Sardinia. Int J. Climatol. 2002, 22, 917-932. [CrossRef]

32. Azorin-Molina, C.; Tijm, S.; Chen, D. Development of selection algorithms and databases for sea breeze studies. Theor. Appl. Climatol. 2011, 106, 531-546. [CrossRef]

33. Yan, H.; Anthes, R.A. The effect of variations in surface moisture on mesoscale circulations. Mon. Weather Rev. 1988, 116, 192-208. [CrossRef]

34. Comin, A.N.; Miglietta, M.M.; Rizza, U.; Acevedo, O.C.; Degrazia, G.A. Investigation of sea-breeze convergence in Salento Peninsula (southeastern Italy). Atmos. Res. 2015, 160, 68-79. [CrossRef]

35. Azorin-Molina, C.; Connell, B.H.; Baena-Calatrava, R. Sea-Breeze Convergence Zones from AVHRR over the Iberian Mediterranean Area and the Isle of Mallorca, Spain. J. Appl. Meteorol. Climatol. 2009, 48, 2069-2085. [CrossRef]

36. Martín, J.; Romero, R. Diurnal moist convection in Majorca under sea breeze conditions: Idealized numerical experiments. In VI Simposio Nacional de Predicción; Agencia Estatal de Meteorología: Madrid, Spain, 2019; pp. 543-551. [CrossRef]

37. Guijarro, J.A.; Heredia, M.A. Climatología de descargas eléctricas nube-tierra en las Islas Baleares. Rev. Climatol. 2004, 4, 9-19.

38. Reiter, E.R. Handbook for Forecasters in the Mediterranean; Tech. Pap. No. 5-75; Environmental Prediction Research Facility, Naval Postgraduate School: Monterey, CA, USA, 1975; p. 344.

39. Azorin-Molina, C.; Sánchez-Lorenzo, A.; Calbo, J. A climatological study of sea breeze clouds in the southeast of the Iberian Peninsula (Alicante, Spain). Atmósfera 2009, 22, 33-49. Available online: https://www.revistascca.unam.mx/atm/index.php/ atm/article/view/8617 (accessed on 5 October 2021).

40. Tomàs-Burguera, M.; Grimalt-Gelabert, M. Maritime, coastal and microcontinental thunderstorm activity in insular areas. A geographical analysis in Mallorca. Boletín Asoc. Geógrafos Españoles 2014, 66, 463-471.

41. Auliciems, A. Weather perception: A subtropical winter study. Weather 1976, 9, 312-316. [CrossRef]

42. Auliciems, A. Towards a psycho-physiological model of thermal perception. Int. J. Biometeorol. 1981, 25, 109-122. [CrossRef] [PubMed]

43. Martínez-Ibarra, E.; Gómez-Martín, M.B.; Armesto-López, X.A.; Pardo-Martínez, R. Climate preferences for tourism: Perceptions regarding ideal and unfavourable conditions for hiking in Spain. Atmosphere 2019, 10, 646. [CrossRef]

44. Alomar-Garau, G. Urbanismo crítico, cartografía y evolución del verde urbano en los planes de ensanche históricos de la ciudad de Palma (Mallorca). ACE Archit. City Environ. 2019, 15, 9039. [CrossRef]

45. González, E.; Hinz, E.; Oteiza, P.; Quiroz, C. Proyecto, Clima y Arquitectura; Instituto de Investigaciones de Arquitectura y Sistemas Ambientales. Facultad de Arq. de Luz, Gustavo Gili, Colección Arquitectura Latinoamericana: Naucalpan de Juárez, México, 1986.

46. Alomar-Garau, G.; Llop-Garau, J. La isla de calor urbana de Palma (Mallorca, Islas Baleares): Avance para el estudio del clima urbano en una ciudad litoral mediterránea. Boletín Asoc. Geógrafos Españoles 2018, 78, 392-418. [CrossRef]

47. Jansà, A. El Clima de les Illes Balears; Lleonard Muntaner: Palma, Spain, 2014.

48. Millán, M.; Salvador, R.; Mantilla, E.; Kallos, G. Photooxidant dynamics in the Mediterranean basin in summer: Results from European research projects. J. Geophys. Res. 1997, 102, 8811-8823. [CrossRef]

49. Lalas, D.P.; Asimakopoulos, D.; Deligiorgi, D.; Helmis, C. Sea-Breeze Circulation and Photochemical Pollution in Athens, Greece. Atmos. Environ. 1983, 16, 531-544. [CrossRef]

50. Romero, R.; Ramis, C. A numerical study of the transport and diffusion of coastal pollutants during the breeze cycle in the Island of Mallorca. Ann. Geophys. 1996, 14, 351-363. [CrossRef]

51. Vives-Vallés, J.A.; La Paz, J.L.; Corujo, M.; Martínez-Cañellas, A.; Galmés, L. Field cross-fertilization between GM and non-GM maize in Mallorca: A Mediterranean insular approach. In Proceedings of the GMCC-15: Seventh GMCC, International Conference on Coexistence between Genetically Modified (GM) and Non-GM Based Agricultural Supply Chains (GMCC), Amsterdam, The Netherlands, 17-20 November 2015. [CrossRef]

52. Fullana-Pericàs, M.; Ponce, J.; Conesa, M.À.; Juan, A.; Ribas-Carbó, M.; Galmés, J. Changes in yield, growth and photosynthesis in a drought-adapted Mediterranean tomato landrace (Solanum lycopersicum 'Ramellet') when grafted onto commercial rootstocks and Solanum pimpinellifolium. Sci. Hortic. 2018, 233, 70-77. [CrossRef]

53. Wade, J.E.; Hewson, E.W. Trees as a Local Climatic Wind Indicator. J. Appl. Meteorol. 1979, 18, 1182-1187. Available online: http:/ /www.jstor.org/stable/26179174 (accessed on 5 October 2021). [CrossRef]

54. Yoshino, M. Studies on wind-shapes trees. Their classification, distribution and significance as a climatic indicator. Climatol. Notes 1973, 12, 1-52.

55. Basterretxea, G.; Garcés, A.; Jordi, A.; Masó, M.; Tintoré, J. Breeze conditions as a favoring mecanism of Alexandrium taylori blooms at a Mediterranean beach. Estuar. Coast. Shelf Sci. 2005, 62, 1-12. [CrossRef]

56. Hind, N. 896. ERIGERON GLAUCUS. Curtis's Bot. Mag. 2018, 35, 359-379. [CrossRef]

57. Psuty, N.P. The coastal foredune: A morphological basis for regional coastal dune development. In Coastal Dunes, Ecology and Conservation. Ecological Studies v. 171; Martinez, M., Psuty, N., Eds.; Springer: Berlin, Germany, 2004; pp. 11-27.

58. Servera, J. Els Sistemes Dunars Litorals de les Illes Balears. Ph.D. Thesis, University of the Balearic Islands, Palma, Spain, 1997. 
59. Masselink, G. Sea breeze activity and its effect on coastal processes near Perth, Western Australia. J. R. Soc. West. Aust. 1996, 79, 199-205.

60. Masselink, G.; Pattiaratchi, C.B. Characteristics of the Sea Breeze System in Perth, Western Australia, and its effect in nearshore wave climate. J. Coast. Res. 2001, 17, 173-187. Available online: https://journals.flvc.org/jcr/article/view/81219 (accessed on 5 October 2021).

61. Ponce de León, S.; Orfila, A. Numerical study of the marine breeze around Mallorca Island. Appl. Ocean. Res. 2013, 40, 26-34. [CrossRef]

62. Rafiq, S.; Pattiaratchi, C.; Janeković, I. Dynamics of the Land-Sea Breeze System and the Surface Current Response in South-West Australia. J. Mar. Sci. Eng. 2020, 8, 931. [CrossRef]

63. Alomar-Garau, G.; Grimalt-Gelabert, M. Air Photo Interpretation for Spatial Analysis of Heritage Agrarian Structures in Mediterranean Settings as Sea-Breezes Proxy-Data. Application to the Island of Mallorca. Remote Sens. 2021, 13, 4652. [CrossRef]

64. Buswell, R.J. Mallorca: The Making of the Landscape; Dundin Academic Press: Edinburgh, UK, 2013.

65. Doolittle, W.E. Stacking Rocks to Transport Water: Folk Aqueduct Bridges of Mallorca and Spanish Colonial California. Sustainability 2020, 12, 5257. [CrossRef]

66. Cursach, M.F. Anàlisi sobre la protecció del patrimoni molinològic a Mallorca, present i futur. In Proceedings of the IV International Molinology Conference, Mallorca, Spain, 1-3 May 2003; Consell Insular de Mallorca: Mallorca, Spain, 2005; Volume 2, pp. 389-408. 